\title{
水熱ホットプレス法を用いた廃コンクリート固化体の フレッシュセメント添加による高強度化
}

\author{
中根裕司・橋田俊之 $\cdot$ 高橋秀明 $\cdot$ 山崎仲道* \\ 東北大学工学部附属破壊力学応用研究施設, 980 仙台市青葉区荒巻字青葉 \\ *高知大学理学部附属水熱化学実験所, 780 高知市曙町 2-5-1
}

\section{Strengthening of Hydrothermal Hot-Pressed Concrete Wastes by the Addition of Fresh Cement}

Yuji NAKANE, Toshiyuki HASHIDA, Hideaki TAKAHASHI and Nakamichi YAMASAKI*

Research Institute for Fracture Technology, Faculty of Engineering, Tohoku University, Aoba, Aramaki, Aoba-ku, Sendai-shi 980 ${ }^{*}$ Research Laboratory of Hydrothermal Chemistry, Faculty of Science, Kochi University, 2-5-1, Akebono-cho, Kochi-shi 780

[Received November 14, 1994; Accepted February 21, 1995]

In order to recycle concrete wastes, a new processing method for solidifying pulverized concrete wastes has been developed using a hydrothermal hot-pressing method. The effect of addition of fresh cement was examined to further increase the strength of solidified concrete wastes. Hydrothermal hot-pressing tests were carried out at $200-250^{\circ} \mathrm{C}$ with the water content of 1030 mass \% under the pressure of $20 \mathrm{MPa}$ for $20 \mathrm{~min}$. Fresh cement of 0-50 mass\% was added to the mixture. It is shown that the formation of tobermorite improved the tensile strength. The tensile strength determined by a Brazilian test reached approximately 13 MPa under the conditions; the temperature : $230^{\circ} \mathrm{C}$, fresh cement content : $\mathbf{5 0}$ mass $\%$, and water content : 30 mass $\%$.

Key-words: Hydrothermal hot-pressing, Concrete wastes, Solidification, Fresh cement, Strength, Tobermorite

\section{1. 緒 言}

コンクリート構造物の老朽化に伴い，コンクリート廃材 の処理技術が環境管理の観点から社会的な課題となってい る1),2). 著者らは, 水熱ホットプレス法を用いることによ り，短時間でコンクリート廃材の粉末を固化しうることを 報告し，コンクリート廃材の再利用技術として提案した ${ }^{3)}$. 水熱ホットプレス法とは，水を添加した粉末をオートク レ一ブ内へ入れ，水熱条件下で加圧する方法であり，機械 的圧搾と水熱反応の効果を同時に利用する固化技術であ $3^{3) \sim 5)}$. 前述のコンクリート廃材の固化条件は, 反応温 度 $120 \sim 250^{\circ} \mathrm{C}$, 加圧力 $20 \mathrm{MPa}$ であり, 反応時間は約 20 分程度であった．合成した固化体の引張強度の範囲は， $1 \sim 5 \mathrm{MPa}$ であった.

コンクリート廃材の固化技術が開発されれば，建築パネ ルなどの建築部材として再利用できることになる．加え て，高強度固化体を作製することができれば，従来主とし て金属材料で構成されてきた機械部品へ廃コンクリート固 化体を適用しうる可能性も生じ，材料のリサイクリングを 考慮した機械要素設計や部材の軽量化にも貢献できること
が期待される.

本研究では, 水熱ホットプレス法により処理したコンク リート廃材の固化体の強度を更に向上させることを目的と

し，フレッシュセメントの添加の影響を検討する．水熱 ホットプレス法を利用した, 新しいコンクリート廃材のリ サイクリング法の開発を目指す.

\section{2. 実験方法}

\section{1 水熱ホットプレス法}

固化合成に用いた水熱ホットプレス用オートクレーブの 模式図を図 1 に示す。本装置は文献3)で使用したものと 同一である.オートクレーブ本体は内径 $30 \mathrm{~mm}$ のピスト ンシリンダー型構造であり, シリンダー内部に水を添加し た試料粉末を充填した後, 上下からピストンに圧力を加え ることにより試料を一軸加圧することができる．ピストン

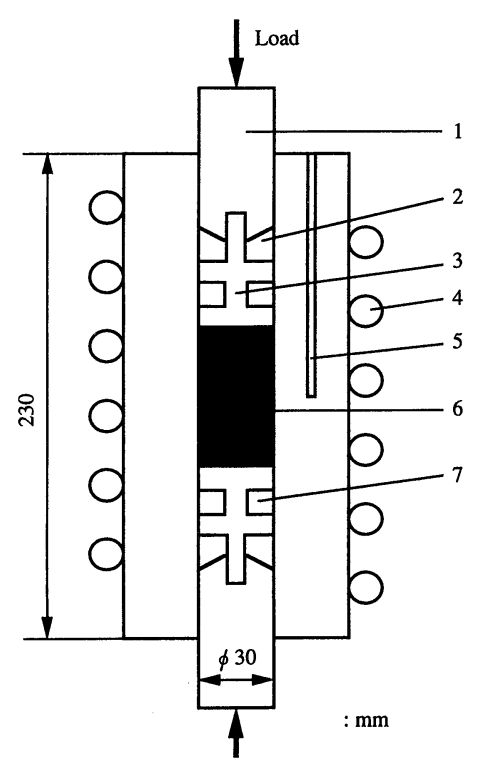

Fig. 1. Autoclave for hydrothermal hot-pressing. 1 : Push rod, 2 : Gland packing, 3 : Cast rod, 4 : Heater, 5 : Thermocouple, 6 : Sample, 7 : Space for water retreat. 
Table 1. X-Ray Fluorescence Analysis Value

\begin{tabular}{|c|c|c|c|c|c|c|c|c|c|c|c|c|}
\hline Material & $\mathrm{SiO}_{2}$ & $\mathrm{Al}_{2} \mathrm{O}_{3}$ & $\mathrm{TiO}_{2}$ & $\mathrm{Fe}_{2} \mathrm{O}_{3}$ & $\mathrm{CaO}$ & $\mathrm{MgO}$ & $\mathrm{Na} 2 \mathrm{O}$ & $\mathrm{K}_{2} \mathrm{O}$ & $\mathrm{SO}_{3}$ & $\mathrm{P}_{2} \mathrm{O} 5$ & $\mathrm{MnO}$ & Balance \\
\hline Concrete Waste & 50.64 & 12.49 & 0.76 & 7.29 & 11.60 & 3.58 & 1.48 & 1.29 & 1.77 & 0.10 & 0.12 & 7.59 \\
\hline Fresh Cement & 21.80 & 6.50 & 0.24 & 1.90 & 61.72 & 1.40 & 1.13 & 1.45 & 2.30 & 0.56 & 0.12 & 1.86 \\
\hline
\end{tabular}

には試料から搾り出された高圧蒸気の逃げ空間があり，こ の空間によって試料中の水分量が調節される. 更に，ピス トンと押し棒の間には，テフロン製グランドパッキンが装 着されており, 上下からの圧力により変形して内部の高圧 蒸気の漏洩を防ぎ，固化反応中の試料を所要の水熱状態に 保つ働きをする．オートクレーブの加熱はシース型ヒー ターで行い，その昇温速度は約 $9^{\circ} \mathrm{C} / \mathrm{min}$ とした. 試料へ の加圧は, $100 \mathrm{kN}$ 容量のインストロン万能試験機を用い た.

\section{2 供試材及び試験方法}

試験に供したコンクリート廃材は，コンクリート工場に 約 1 年間放置されていたものであり，骨材が混入されて いる状態のままボールミルにより平均粒径 $35 \mu \mathrm{m}$ に粉砕 したものを出発原料とした．また，添加したフレッシュセ メント粉末は一般のポルトランドセメント（平均粒径 4.9 $\mu \mathrm{m})$ である. 両者の蛍光 $\mathrm{X}$ 線定量分析結果を表 1 に示 す.

コンクリート廃材に，フレッシュセメント粉末を重量比 で 0, 10,20,30, 50 mass\%配合したものを対象に水熱ホッ トプレス法により固化した. 加えた蒸留水の量は 10,20 , 30 mass\%である。 また，反応温度は $200,230,250^{\circ} \mathrm{C}$ あ゙あ る.上下方向からピストンに加える圧力は $20 \mathrm{MPa}$ とし た. 上述の所定の反応温度に達してからの保持時間はすべ て20 min とした.

水熱ホットプレス法で得られた固化体との比較のため に，水中養生した試験片を作製した．上述と同一のコンク リート廃材粉末に，所定の量のフレッシュセメントと水分 量を30 mass\%添加し，水熱ホットプレス法で作製した固 化体と同型の試験片にキャスティングした後，28日間の 水中養生を行ったものを試験に供した（以降これを水中養 生モルタルと呼ぶこととする)．得られた円盤状固化体は エメリー紙\#600にて研磨を行った。

強度評価は，圧裂試験により実施した。水熱ホットプレ ス法で得られた固化体については，10日間室内保管を 行ったものを強度評価試験に用いた．測定した破断荷重 （最大荷重）を次式に代入して引張強度， $\sigma_{\mathrm{f}}$ を算出した.

$$
\sigma_{\mathrm{f}}=2 P_{\max } / \pi d t
$$

ここで, $P_{\max }$ は最大荷重, $d$ は試験片直径, $t$ は試験片板 厚である. 試験時のクロスヘッドスピードは $0.2 \mathrm{~mm} / \mathrm{min}$ とした. 圧裂試験の後, 固化体の破面の様子を走査型電子 顕微鏡（SEM）により観察した. 粉末 X 線回折による分 析も併せて行った。

\section{3. 試験結果及び考察}

セメントを配合したコンクリート廃材の固化体のかさ比 重は1900～ $2100 \mathrm{~kg} / \mathrm{m}^{3}$ の範囲内にあり，セメントの配合 比が大きくなるほど，また水分量が多くなるほど比重は大 きくなった.

まず，適切な温度条件を選択するために，水分量が 10 mass\%の固化体の試験結果について記述する. 図 2 に, 水分量 10 mass $\%$ の条件で合成した固化体の引張強度とセ メント配合比との関係を各反応温度について示す. 図中に は比較のため作製した水中養生モルタルの引張強度も示し てある. 反応温度が高くなるほど, 引張強度が上昇するこ

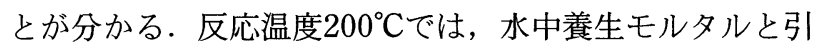
張強度に大きな差はないものの, $230,250^{\circ} \mathrm{C} て ゙$ 固化された ものは水中養生モルタルの 1.5 倍以上になり, $6 \mathrm{MPa}$ 程度 の值に達している. $230^{\circ} \mathrm{C} と 250^{\circ} \mathrm{C}$ 結果には大きな強度 の差異は観察されない. 図 3 には, セメント配合比50 mass $\%$, 反応温度 $200,230,250^{\circ} \mathrm{C}$ で合成された固化体と, 水中養生モルタルの圧裂試験後の破面の SEM 写真を示 す. 水中養生モルタル（図 $3(\mathrm{a})$ ) には, 微細な䋐維状物 質が析出している. 水熱ホットプレス法で合成された試験 片には, 板状の結晶が成長している様子が分かる. 反応温 度が増大するにつれて板状結晶の寸法は大きくなってい る.この板状結晶は他のフレッシュセメント配合比につい ても観察され, 配合比が増大するほど結晶の寸法が大きく

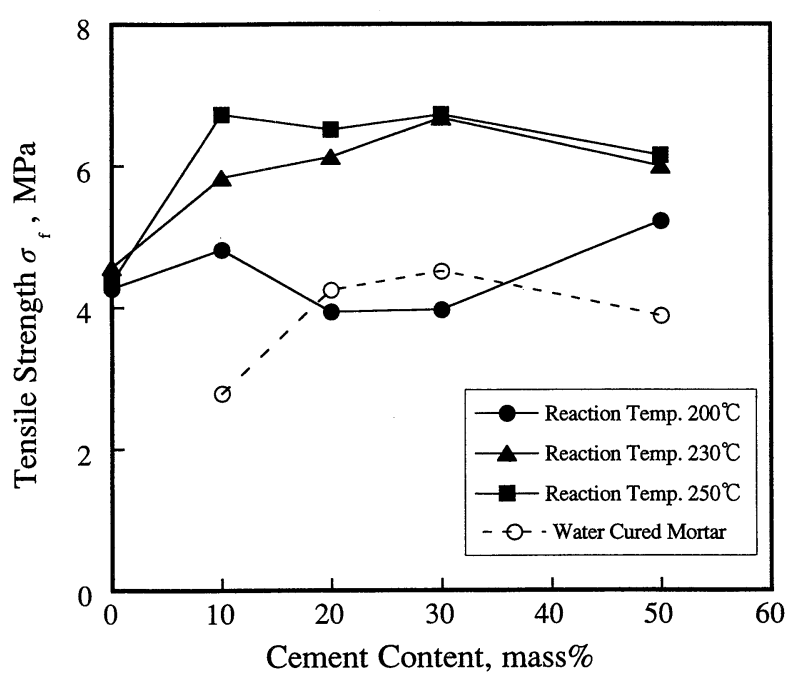

Fig. 2. Relationship of tensile strength vs. cement content. (Water content : 10 mass\%) 

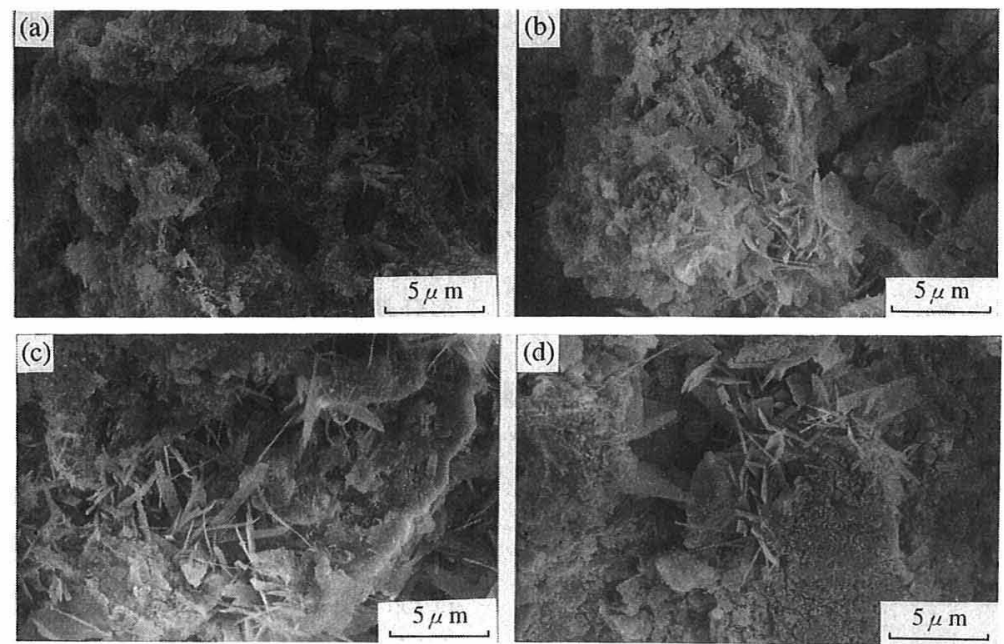

Fig. 3. SEM photographs of fracture surfaces.

Reaction conditions are cement content 50 mass \%, water content 10 mass $\%$, (a) water curing for $28 \mathrm{~d}$, (b) $200^{\circ} \mathrm{C},\left(\right.$ c) $230^{\circ} \mathrm{C}$, (d) $250^{\circ} \mathrm{C}$

なることも観察されている. 図 4 に, 図 3 で示した固化 体と出発材料の粉末 X 線回折結果を示す. 水中養生モル タルには, セメント水和物である $\mathrm{Ca}(\mathrm{OH})_{2}$ や C-S-H の 存在を確認できる. SEMにより観察された結晶は $\mathrm{Ca}(\mathrm{OH})_{2}$ や C-S-H 等のセメント水和物であると考えて よい。 また，水熱ホットプレス法による固化体では，

(a) Before Solidification Concrete Waste 50 mass $\%$, Cement 50 mass $\%$

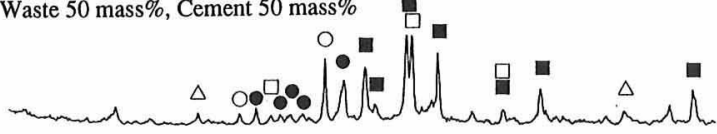

(b) Water Curing for 28days

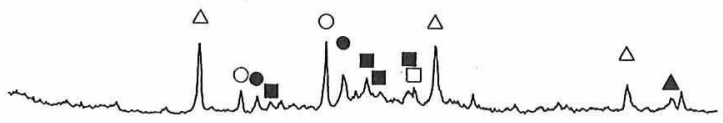

(c) Reaction Temperature $200^{\circ} \mathrm{C}$

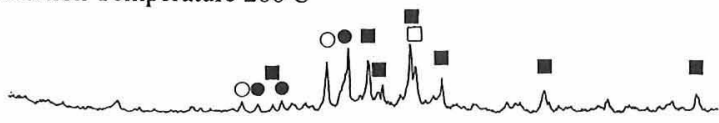

(d) Reaction Temperature $230^{\circ} \mathrm{C}$

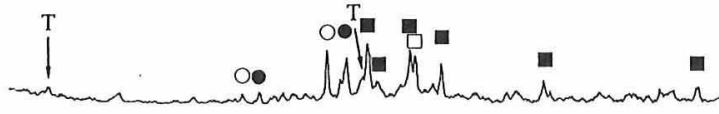

(e) Reaction Temperature $250^{\circ} \mathrm{C}$

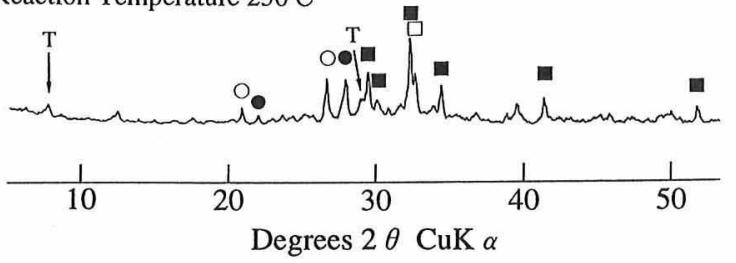

Fig. 4. X-ray diffraction profiles.

Reaction conditions are cement content 50 mass\%, water content 10 mass\%. Symbols $\bigcirc$ Quartz, Feldspar, $\square 2 \mathrm{CaO} \cdot \mathrm{SiO}_{2}$, $3 \mathrm{CaO} \cdot \mathrm{SiO}_{2}, \triangle \mathrm{Ca}(\mathrm{OH})_{2}, \triangle \mathrm{C}-\mathrm{S}-\mathrm{H}, \mathrm{T}$ : Tobermorite.
$\mathrm{Ca}(\mathrm{OH})_{2}$ のピークは顕著には現れていない。しかしなが ら, 反応温度が $230^{\circ} \mathrm{C}$ 以上になると $1.1 \mathrm{~nm}$ トバモライト $\left(\mathrm{Ca}_{5}(\mathrm{OH})_{2} \mathrm{Si}_{6} \mathrm{O}_{16} \cdot 4 \mathrm{H}_{2} \mathrm{O}\right)$ のピークが明瞭に観察される ようになる.このトバモライトのピークは $\mathrm{X}$ 線図上では, 回折角度 $2 \theta=7.8^{\circ}, 29.0^{\circ}$ (格子面間距離 $=1.13 \mathrm{~nm}, 0.308$ $\mathrm{nm}$ ）にあたる.したがって, 図 3 の水熱ホットプレス法 による固化体で観察された板状結晶はトバモライトである と判断される. トバモライトが析出し，それらが複雑に絡 み合うことにより機械的強度が上昇することが知られてい る(3),6),7). したがって図 2 で, 反応温度 $230,250^{\circ} \mathrm{C}$ で引張 強度の上昇が得られたのは，トバモライトが生成されたた めであると判断される。この結果に基づき，反応温度 $230^{\circ} \mathrm{C}$ の条件で水分量の固化体強度に及ぼす影響を検討し た.

図 5 に，水分量の固化体引張強度に及ぼす影響を示す. 水分量を増加させると, 固化体の引張強度が上昇している

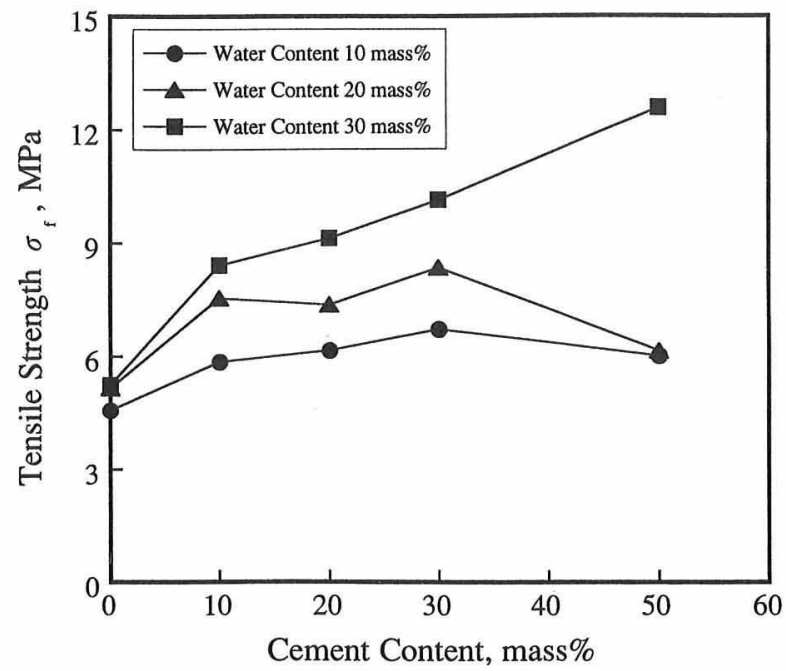

Fig. 5. Relationship of tensile strength vs. cement content. (Reaction temperature $: 230^{\circ} \mathrm{C}$ ) 
ことが分かる、また，セメントの配合比が30 mass\%まで は, いずれの水分量で合成した固化体も引張強度が上昇す る。配合比が50 mass\%に増加すると，水分量10,20 mass\%のものは若干強度の低下が見られるものの，水分 量30 mass\%については強度は更に改善されている. 配合
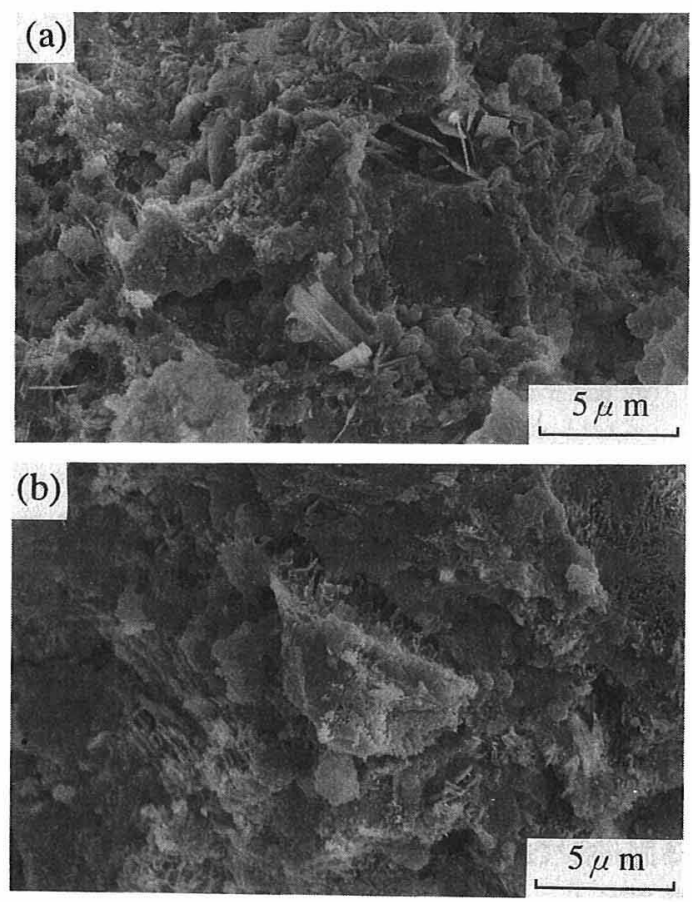

Fig. 6. SEM photographs of fracture surfaces.

Reaction conditions are reaction temperature $230^{\circ} \mathrm{C}$, cement content 50 mass $\%$, water content (a) 20 mass $\%$, (b) 30 mass $\%$.

(a) Water Content 10 mass $\%$

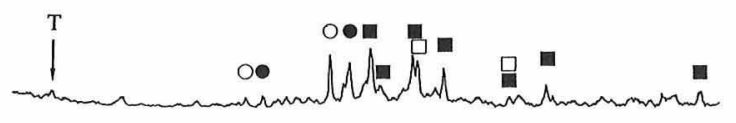

(b) Water Content 20 mass\%

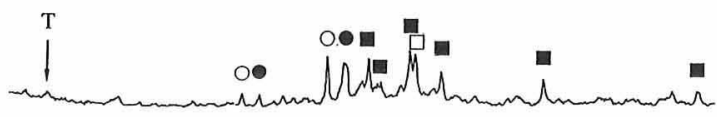

(c) Water Content 30 mass $\%$

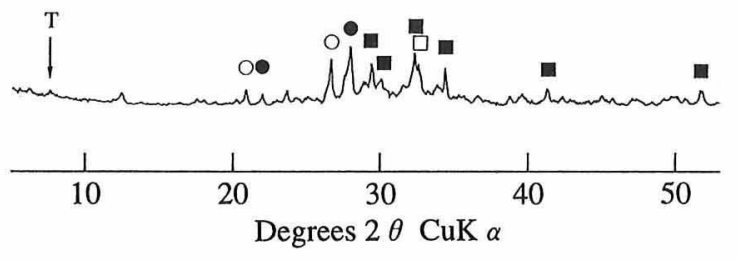

Fig. 7. X-ray diffraction profiles.

Reaction conditions are reaction temperature $230^{\circ} \mathrm{C}$, cement content 50 mass\%.

Symbols $\bigcirc$ Quartz, Feldspar, $\square 2 \mathrm{CaO} \cdot \mathrm{SiO}_{2}$, $3 \mathrm{CaO} \cdot \mathrm{SiO}_{2}$, $\mathrm{T}$ : Tobermorite.
比50 mass\%, 水分量30 mass\%で合成された固化体の引 張強度は約 $13 \mathrm{MPa}$ であり, セメントを配合していない固 化体の 2 倍程度の引張強度が得られた. また, 水中養生 モルタルと比較すると $3 \sim 4$ 倍の引張強度となる. 図 6 に は, セメント配合比50 mass\%, 水分量20, 30 mass\%で合 成された固化体の圧裂試験後の破面の SEM 写真を示す. 水分量 10 mass\%（図 3 (c)）では $5 \mu \mathrm{m}$ 程度の板状のトバ モライトの結晶が析出していたが, 水分量が増大するにつ れ板状のトバモライトの結晶は観察されなくなる傾向にあ り，特に水分量が30 mass\%（図 6 (b)）になると，1〜2 $\mu \mathrm{m}$ 程度の大きさの針状物質が，粒子同士の間を埋めるよ うに緻密に析出し, 網目状に連結している様子がうかがわ れる. 図 7 に, 図 6 に示した固化体の粉末 X 線回折結果 を示す. 水分量を増した場合に沶いても, 回折角度 $2 \theta$ $=7.8^{\circ}$ (格子面間距離 $1.13 \mathrm{~nm}$ ) のトバモライトのピークは 認められる. したがって, 図 6 に観察される緻密な組織 への変化は, 板状のトバモライトから針状のトバモライト の生成へと変化したためと推察される. 図 5 に示されて いる水分量 30 mass $\%$ の試験片で特に強度が上昇したの は，上述の針状物質が生成し緻密化が促進されたことによ るものと考えられる.

本研究では, コンクリート工場に約 1 年放置された材 料をコンクリート廃材のモデル材として使用した．今後, 長年経過した実際のコンクリート廃材を用いた本法の適用 性に関する検討が重要となろう。

\section{4. 結 言}

水熱ホットプレス法により処理したコンクリート廃材の 固化体の強度を更に向上させることを目的とし, フレッ シュセメントの添加の影響を検討することにより以下の知 見を得た.

セメント粉木をコンクリート廃材に配合することによ り，コンクリート廃材のみで合成した固化体よりも引張強 度の高い固化体が合成できた。 セメント配合比50 mass $\%$, 水分量 30 mass $\%$, 反応温度 $230^{\circ} \mathrm{C}$, 反応時間 20 分で合成された固化体の引張強度は最大值を示し, 約 13 $\mathrm{MPa}$ であった，この強度は，水中養生した通常モルタル の3〜4 倍程度のものである.

\section{文献}

1) 西岡 守, 山崎仲道, ウェイストリソース, 24, 7-11 (1991).

2) 吉兼 亨, コンクリート工学, 129, No. 7, 96-101 (1991).

3) 中根裕司, 佐藤一志, 高橋秀明, 山崎仲道, 橋田俊之, $J$. Ceram. Soc. Japan, 102, 405-07 (1994).

4) 山崎仲道, 柳沢和道, 西岡 守, ニューセラミックス, No. 10, 81-86 (1989)

5）山崎仲道, 柳沢和道, 西岡 守, ニューセラミックス, No. 12, 67-71 (1989).

6）鈴木一孝, 浅川邦治, 土田幸宏, 伊藤祐敏, 福尾券一, 晏協, 85, 440-47 (1977).

7）井須紀文, 寺村敏史, 佐々木 香, 石田秀輝, 光田 武, セ ラミックス協会1993年年会講演予稿集 (1993) pp. 50405 . 